\section{Relationship between weight, volume and specific gravity of goose eggs before incubation}

\section{ABSTRACT}

In this study, the relationships between the weight, volume and specific gravity of eggs are revealed by calculating egg's volume and specific gravity depending on the weight of the egg, breadth and length, which are only three variables, with mathematical equations. Eggs to three goose genotypes, Grey China, Linda and Native geese from Aksaray region taken from six breeders were used. Eggs $(n=481)$ were weighed and Length, Breadth measurements made with a precision of $0.01 \mathrm{~mm}$. Average weights in genotypes from large to small in Linda, Native and Chinese geese were detected as; $165.9,137.2$ and $131.1 \mathrm{~g}$, respectively, and the average egg volume was found as; 152.0, 126.0 and $120.3 \mathrm{~cm}^{3}$, respectively. Specific gravity from large to small in Linda, China and Native has occurred as; $1.092,1.091$ and $1.089 \mathrm{~g} / \mathrm{cm}^{3}$. Egg volume was calculated with mathematical equations and results were close to real, and accordingly the calculated Specific gravity was also detected to be realistic. These results were obtained easily by only three variables, egg weight, and Length and Breadth values. This method can pave the way to obtain a lot of information about the egg with Specific gravity.

Keywords: Correlation, goose, egg, regression, specific gravity

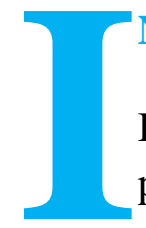

\section{NTRODUCTION}

Breeding process of geese in an incubator involves extra procedures compared to other types of poultry. At the end of this difficult procedure followed, the desired level of incubation efficiency cannot be achieved (Golz, 1991; Tilki and İnal, 2004a; Karabulut et al., 2017). Hatching efficiency has a high variation in geese, about $50-90 \%$, and this variation is difficult to explain (Tilki and İnal, 2004a; Ramos et al., 1989; Toth, 1991; Özbey, 1998; Arslan and Saatçi, 2003; Önk and Kırmızıbayrak, 2019).

Offspring rate is the most important reason that reduces hatching efficiency, which can be understood by the incubation of the egg. With an appropriate flock management, the fertility rate can be increased and the decline in hatchery yield can be prevented. The handicap of goose breeders is that they try to use all of the goose eggs in incubation because they are few and valuable. This causes exceeding the external quality standards in the hatching eggs, and therefore reduces the hatching efficiency (Karabulut et al., 2017; Önk and Kırmızıbayrak, 2019). Incorrect storage of eggs is an important factor that reduces hatchability. After the egg is laid, there is a decrease in its weight as it constantly loses water, and this decrease occurs rapidly if the appropriate humidity and heat environment is not provided.

\section{How to cite this article}

Karabulut, O. (2021). Relationship between weight, volume and specific gravity of goose eggs before incubation. Journal of Advances in VetBio Science and Techniques, 6(2), 90-99. https://doi.org/10.31797/vetbio.929031
Research Article

Osman KARABULUT

Department of Biometrics,

Faculty of Veterinary Medicine, Aksaray

University,

Aksaray, Turkey

ORCID-

$\underline{0000-0002-8142-2365}$

Correspondence

Osman KARABULUT

okarabulut02@gmail.com

Article info

Submission: 25-04-2021

Accepted: 30-07-2021

Online First: 13-08-2021

e-ISSN : 2548-1150

doi prefix: $10.31797 /$ vetbio

- http://dergipark.org.tr/vetbio

This work is licensed under a Creative Commons Attribution 4.0 International License (c) (7) 
This loss of weight causes a series of reactions that cause the egg to spoil and the efficiency of the hatch is reduced (Rahn, 1977; Carey, 1994; Erensayın, 2000).

The presence of weight loss depending on the time of the egg refers to the variability of the egg over time. In other words, when talking about egg weight, weighing at a certain time should come to mind.

The average weight of goose eggs has a wide variation between approximately 123 and $185 \mathrm{~g}$ (Paganelli et al., 1974; Saatçi et al., 2002; Saatçi et al., 2005; Rabsztyn et al., 2010; Nedomová and Buchar, 2014; Hamadani et al., 2016; Kumbar et al., 2016; Ahmad et al., 2017). These differences may result from genetic factors such as race and age, as well as environmental factors such as care, feeding, breeding system and region differences. Arroyo (1990) used goose eggs of Africa, China, Toulouse and Embden in his study and reported that the egg weight was $170,173,168$ and $183 \mathrm{~g}$, respectively. Tilki and Inal (2004b) found that the average egg weight was $154.9 \mathrm{~g}$ in their study on France White geese and increased significantly after 2 years of age. Hamadani (2016) found the average egg weight as $136.65 \mathrm{~g}$ in Kashmir Weight geese; Razmaite (2013) found the average egg weight as $123.40 \mathrm{~g}$ in the first spawning season and $186.69 \mathrm{~g}$ in the second season.

Due to the variability of egg weight, it alone is not enough to evaluate the egg. But it can gain a powerful meaning with specific gravity. Because, when looking at the specific gravity formula, it suggests that there is a positive correlation between weight and specific gravity. Normally the specific gravity corresponds to an approximately constant value, but as the weight decreases, the specific gravity is expected to decrease as well.

It is the safest method to calculate specific gravity according to Archimedes principle. Saatçi et al. (2002) calculated the specific gravity of domestic goose eggs as 1.113 in Kars region,
Arroyo (1990) calculated it as 1.079, 1.08, 1.08 and 1.079 in Africa, China, Toulouse and Embden races respectively, Hamadani et al. (2016) detected it as $1.09 / \mathrm{cm}^{3} \mathrm{~g}$ in Kashmir Anz geese in Kashmir Valley, India. It is seen that specific gravity values differ in studies conducted on some poultry animals other than geese. Çetingül and İnal (2009) detected the specific gravity in Nick Brown breed chickens as approximately $1.082 \mathrm{~g} / \mathrm{cm}^{3}$. Nemati (2020) found the specific gravity as $1.07 \mathrm{~g} / \mathrm{cm}^{3}$ in Japanese quails.

Volume is a variable used in the calculation of specific gravity, and the volume of the egg does not differ over time. In other words, while the specific gravity and egg weight show an alternation, the volume is constant. Calculating the volume according to Archimedes' principle is the safest. The average volume of goose eggs has a wide variation between approximately 125 and $175 \mathrm{~cm}^{3}$ (Paganelli et al., 1974; Saatçi et al., 2002; Nedomová and Buchar, 2014; Kumbar et al., 2016). There is a positive correlation between volume and weight. Paganelli et al. (1974) calculated the volume of Embden Geese as $158.74 \mathrm{~cm}^{3}$ depending on the egg weight.

When examining specific gravity, calculating volume or specific gravity according to Archimedes principle is both difficult and time consuming. It requires a series of difficult operations performed by immersion in water (Hamilton, 1982). Instead, it will be more accurate to use mathematical formulas that calculate the volume with a little error. Since the volume of the egg does not change, it will be appropriate to examine the weight and specific gravity of the eggs together with the volume.

Recently, photographic imaging techniques have been used frequently to obtain information about egg morphology (Lawrence et al., 2006; Sunardi, 2017; Adegbenjo et al., 2020). Length and breadth are frequently used variables in these techniques (Nedomová and Buchar, 2014; Narushin, 2005). Depending on these two 
variables or egg weight, many other variables of the egg can be predicted (Çopur-Akpınar et al., 2017; Alaşahan et al., 2019; Karabulut, in press).

The aim of this study is to obtain information about the weight and specific gravity of eggs with unknown storage history by easily calculating the volume and specific gravity of eggs depending on the three variables of length, breadth and egg weight. For this purpose, mathematical equations will be used instead of Archimedes principle.

\section{MATERIAL and METHOD}

\section{Materials}

Aksaray is a province in the South east of Tuz Gölü, which has a latitude of $38^{\circ} \mathrm{N}$ and longitude of $34^{\circ} \mathrm{E}$, and an altitude of $980 \mathrm{~m}$. Although this region has a continental climate, the air temperature from January to June, which is the laying season of geese, varies between -19-40 ${ }^{\circ} \mathrm{C}$ and relative humidity between $40 \%$ and $85 \%$ (Yayvan, 2008; 2014; Eskin, 2017; ÇŞB, 2021). Breeders brought the eggs to the hatchery in plastic containers or cardboard boxes, supplemented with straw, hay or fodder. They stated that they kept the eggs in the barn until they were brought to the hatchery. In the study, eggs of three goose genotypes; Grey China, Linda and Native geese of Aksaray region, taken from six breeders in Aksaray region were evaluated. China and Linda breeds have been found pure and most of the Native geese of Aksaray region are gray and piebald colored geese, but very few of them have blood from China goose and other breeds. The study was conducted on a total of 481 eggs and the result as follows; Egg distributions from 1st breeder to 6th breeders are 100, 6, 287, 52, 13 and 23, respectively, and the distribution of these eggs by genotypes is 113, 32 and 336 in Grey China,
Linda and Native geese of Aksaray region, respectively.

To measure weight, the eggs were weighed on a scale with $1 \mathrm{~g}$ sensitivity. For the calculation of egg volume, the distance between the two tip points of the long axis of the egg was taken as Length and the distance at the widest part of the short axis as Breadth Measurements were carried out with a digital caliper capable of measuring $200 \mathrm{~mm}$ distance with a precision of $0.01 \mathrm{~mm}$.

\section{Methods}

Egg specific gravity was calculated with its known formula.

Specific gravity $=\frac{\text { Egg weight }}{\text { Egg volume }}$

Actual measurement values were used as egg weight. Egg volume was calculated based on the ellipse shape of the egg (Preston, 1974).

Egg volume $=\mathrm{KvLB}^{2}$ Here; $\mathrm{Kv}=0.507, \mathrm{~L}$ : Length, B: Breadth

The coefficient $(\mathrm{Kv})$ for the egg volume in the formula is the coefficient corresponding to the egg of Anser fabalis, which weighs $142.6 \mathrm{~g}$, reported by Hoyt (1979) from Schönwetter.

\section{Statistics}

Comparison of genotype and breeders for each trait was made by OneWay ANOVA, and differences were made by Duncan Test. Correlations between variables were determined with Pearson Correlation. Analyzes were made in SPSS package program (IBM, 2013).

\section{RESULTS}

The differences between the genotypes of the characteristics related to the weight, volume and specific gravity of the egg have been given in Table 1. 
Table 1. Differences in Egg weight, Egg volume and Specific gravity by genotypes

\begin{tabular}{|c|c|c|c|c|c|c|c|c|}
\hline Variables & Genotypes & $\mathbf{N}$ & $\overline{\mathbf{x}}$ & $\mathbf{S} \overline{\mathbf{x}}$ & Min & Max & $\mathrm{CV}$ & $\mathbf{p}$ \\
\hline \multirow{4}{*}{ Egg weight (g) } & Native & 336 & $137.2^{\mathrm{b}}$ & 0.793 & 101 & 191 & 10.60 & \multirow{3}{*}{$* * *$} \\
\hline & China & 113 & $131.1^{\mathrm{c}}$ & 1.110 & 98 & 164 & 8.99 & \\
\hline & Linda & 32 & $165.9^{\mathrm{a}}$ & 2.492 & 141 & 190 & 8.50 & \\
\hline & Total & 481 & 137.7 & 0.730 & 98 & 191 & 11.63 & \\
\hline \multirow{4}{*}{ Egg volume $\left(\mathrm{cm}^{3}\right)$} & Native & 336 & $126.0^{\mathrm{b}}$ & 0.762 & 94.3 & 175.7 & 11.09 & \multirow{3}{*}{$* * *$} \\
\hline & China & 113 & $120.3^{c}$ & 1.054 & 93.1 & 153.4 & 9.32 & \\
\hline & Linda & 32 & $152.0^{\mathrm{a}}$ & 2.229 & 128.9 & 175.1 & 8.30 & \\
\hline & Total & 481 & 126.4 & 0.689 & 93.1 & 175.7 & 11.95 & \\
\hline \multirow{4}{*}{$\begin{array}{l}\text { Specific gravity } \\
\qquad\left(\mathrm{g} / \mathrm{cm}^{3}\right)\end{array}$} & Native & 336 & 1.089 & 0.001 & 0.890 & 1.150 & 1.89 & \multirow{3}{*}{ NS } \\
\hline & China & 113 & 1.091 & 0.002 & 0.950 & 1.130 & 2.39 & \\
\hline & Linda & 32 & 1.092 & 0.002 & 1.060 & 1.120 & 1.24 & \\
\hline & Total & 481 & 1.090 & 0.001 & 0.890 & 1.150 & 1.98 & \\
\hline
\end{tabular}

***: $\mathrm{p}<0.001$, NS: No significant, $\mathrm{n}$ : number of eggs, $\mathrm{x} \overline{\mathrm{i}}$ mean, Sx$\overline{\mathrm{i}}$ standard error, CV: coefficient of variance, $\mathrm{p}$ : significance

The difference between genotypes in terms of egg weight and volume was found to be very significant $(\mathrm{p}<0.001)$. Among the genotypes, in terms of egg weight averages, it was observed that Linda was the highest and Chinese geese were the lowest. Egg weights averages in genotypes from large to small occurred as follows; Linda, Native and Chinese, respectively. Egg volume was calculated and the order of the averages in genotypes was found to be similar to the egg weight order. Its specific gravity was observed to be similar between genotypes $(\mathrm{p}>0.05)$.

The regressions where egg weight determines egg volume and specific gravity according to genotypes have been given in Figure 1 .
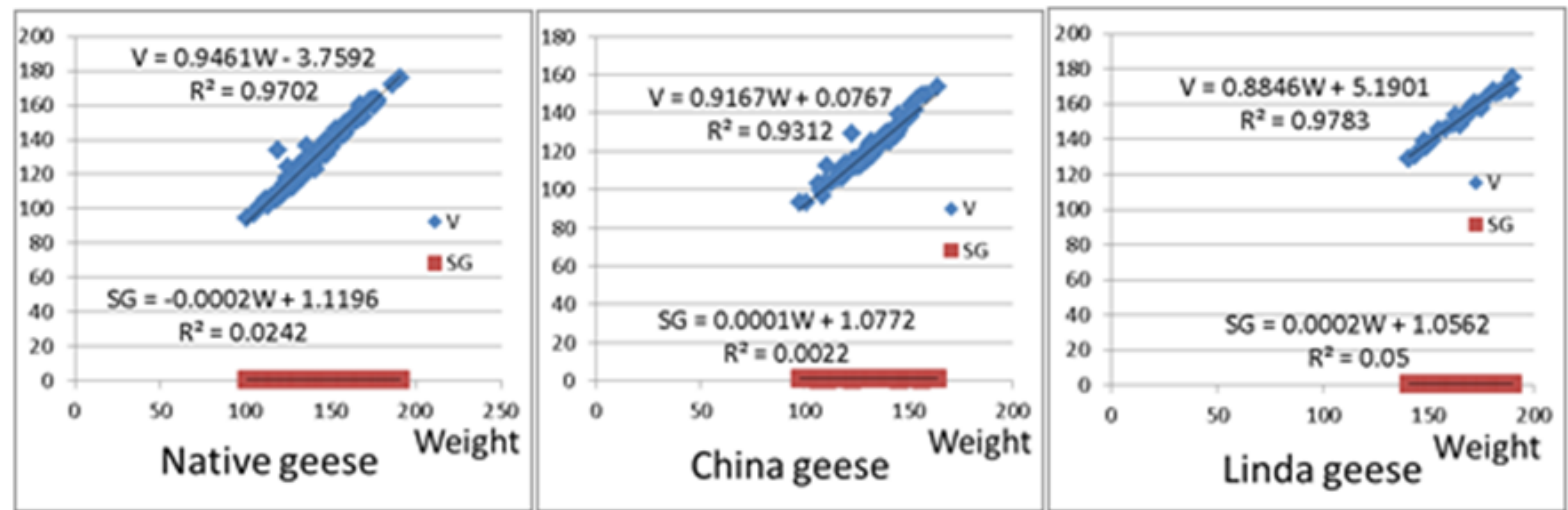

Fig 1. Regressions in which Egg weight determines Egg volume and Specific gravity according to genotypes.

In regression where egg weight determines egg volume, determination coefficients have taken values close to 1 . In regression where egg weight determines the specific gravity in genotypes, determination coefficients have taken values far from 1.
Correlations between Egg weight, Egg volume and Specific gravity according to genotypes have been given in Table 2 . 
Table 2. Correlations between Egg weight, Egg volume and Specific gravity by genotypes.

\begin{tabular}{|ccccccc|}
\hline \multirow{2}{*}{$\mathbf{r}$} & \multicolumn{2}{c}{ Native $(\mathbf{n}=\mathbf{3 3 6})$} & \multicolumn{2}{c|}{ China $(\mathbf{n}=\mathbf{1 1 3})$} & \multicolumn{2}{c|}{ Linda $(\mathbf{n}=\mathbf{3 2})$} \\
\hline \multirow{2}{*}{ Volume } & Weight & Volume & Weight & Volume & Weight & Volume \\
\cline { 2 - 7 } & $\begin{array}{c}0.985 \\
(\mathrm{p}<0.001)\end{array}$ & & 0.965 & & 0.989 \\
$(\mathrm{p}<0.001)$ & & $\begin{array}{c}(\mathrm{p}<0.001) \\
\end{array}$ \\
\hline \multirow{2}{*}{ Specific gravity } & -0.157 & -0.324 & 0.047 & -0.215 & 0.229 & 0.085 \\
$(\mathrm{p}<0.01)$ & $(\mathrm{p}<0.001)$ & $(\mathrm{p}>0.05)$ & $(\mathrm{p}<0.01)$ & $(\mathrm{p}>0.05)$ & $(\mathrm{p}>0.05)$ \\
\hline
\end{tabular}

A very high positive correlation was found between egg weight and volume $(p<0.001)$. Considering the correlations of specific gravity with egg weight and volume, significant negative correlations were found with both variables in Native geese and just volume in China goose $(p<0.01, p<0.001)$ but not seen either in Linda $(\mathrm{p}>0.05)$.
The differences among the breeders of the variables related to the weight, volume and specific gravity of the egg have been given in Table 3. According to the breeders, a significant difference was found in all variables $(\mathrm{p}<0.001)$.

Table 3. Differences in Egg weight, Egg volume and Specific gravity according to Breeders.

\begin{tabular}{|c|c|c|c|c|c|c|c|c|}
\hline Variables & Breeders & $\mathbf{n}$ & $\overline{\mathbf{x}}$ & $\mathbf{S} \overline{\mathbf{x}}$ & Min & Max & $\mathbf{C V}$ & $\mathbf{P}$ \\
\hline \multirow{7}{*}{ Egg weight (g) } & 1.Breeder & 100 & $131.8^{\mathrm{bc}}$ & 1.210 & 98.0 & 164.0 & 9.18 & \\
\hline & 2.Breeder & 6 & $146.2^{\mathrm{a}}$ & 8.284 & 116.0 & 167.0 & 13.88 & \\
\hline & 3.Breeder & 287 & $138.8^{\mathrm{ab}}$ & 0.965 & 105.0 & 190.0 & 11.78 & $* * *$ \\
\hline & 4.Breeder & 52 & $143.3^{\mathrm{a}}$ & 2.603 & 101.0 & 191.0 & 13.10 & \\
\hline & 5.Breeder & 13 & $125.9^{c}$ & 2.098 & 109.0 & 135.0 & 6.01 & \\
\hline & 6.Breeder & 23 & $140.3^{\mathrm{ab}}$ & 2.634 & 119.0 & 160.0 & 9.00 & \\
\hline & Total & 481 & 137.7 & 0.730 & 98.0 & 191.0 & 11.63 & \\
\hline \multirow{7}{*}{$\begin{array}{l}\text { Egg volume } \\
\qquad\left(\mathrm{cm}^{3}\right)\end{array}$} & 1. Breeder & 100 & $121.2^{\mathrm{bc}}$ & 1.135 & 93.1 & 153.4 & 9.36 & \\
\hline & 2. Breeder & 6 & $135.1^{\mathrm{a}}$ & 8.658 & 105.2 & 160.7 & 15.70 & \\
\hline & 3. Breeder & 287 & $127.4^{\mathrm{ab}}$ & 0.903 & 97.2 & 175.1 & 12.01 & $* * *$ \\
\hline & 4. Breeder & 52 & $131.4^{\mathrm{a}}$ & 2.461 & 94.3 & 175.7 & 13.51 & \\
\hline & 5. Breeder & 13 & $112.9^{c}$ & 1.798 & 96.6 & 121.3 & 5.74 & \\
\hline & 6. Breeder & 23 & $130.1^{\mathrm{ab}}$ & 2.657 & 109.2 & 149.2 & 9.79 & \\
\hline & Total & 481 & 126.4 & 0.689 & 93.1 & 175.7 & 11.95 & \\
\hline \multirow{7}{*}{$\begin{array}{l}\text { Specific gravity } \\
\qquad\left(\mathrm{g} / \mathrm{cm}^{3}\right)\end{array}$} & 1. Breeder & 100 & $1.088^{\mathrm{b}}$ & 0.003 & 0.950 & 1.126 & 2.344 & \\
\hline & 2. Breeder & 6 & $1.085^{\mathrm{b}}$ & 0.010 & 1.040 & 1.106 & 2.342 & \\
\hline & 3. Breeder & 287 & $1.090^{\mathrm{b}}$ & 0.001 & 0.890 & 1.138 & 1.905 & $* * *$ \\
\hline & 4. Breeder & 52 & $1.092^{\mathrm{b}}$ & 0.002 & 1.056 & 1.147 & 1.494 & \\
\hline & 5. Breeder & 13 & $1.115^{\mathrm{a}}$ & 0.004 & 1.089 & 1.133 & 1.390 & \\
\hline & 6. Breeder & 23 & $1.079^{\mathrm{b}}$ & 0.003 & 1.049 & 1.106 & 1.462 & \\
\hline & Total & 481 & 1.090 & 0.001 & 0.890 & 1.147 & 1.985 & \\
\hline
\end{tabular}

***: $\mathrm{p}<0,001, \mathrm{NS}$ : No significant, CV: Coefficient of variance

In terms of egg weight average, the highest averages were in the 2nd Breeder and 4th Breeder; 146.2 and $143.3 \mathrm{~g}$, the lowest averages were 131.8 and $125.9 \mathrm{~g}$ in $1 \mathrm{st}$ Breeder and 5th Breeder, and 3rd Breeder and 6th Breeder were placed in the middle with 138.8 and $140.3 \mathrm{~g}$, 
respectively. In terms of egg volume averages, the highest averages were 135.1 and $131.4 \mathrm{~cm}^{3}$ in the 2nd Breeder and 4th Breeder, respectively, the lowest averages were 121.2 and $112.9 \mathrm{~cm}^{3}$ in 1st Breeder and 5th Breeder, and with 127.4 and $130.1 \mathrm{~cm}^{3}$, 3rd Breeder and 6th Breeder were placed in the middle. With these rates, it was found to be similar to the difference in egg weight in terms of differences. The order in specific gravities was different from the weight and volume, and there was only a difference due to the size of the specific gravity of the 5th Breeder's eggs. The regressions where egg weight determines egg volume and specific gravity have given in Figure 2.

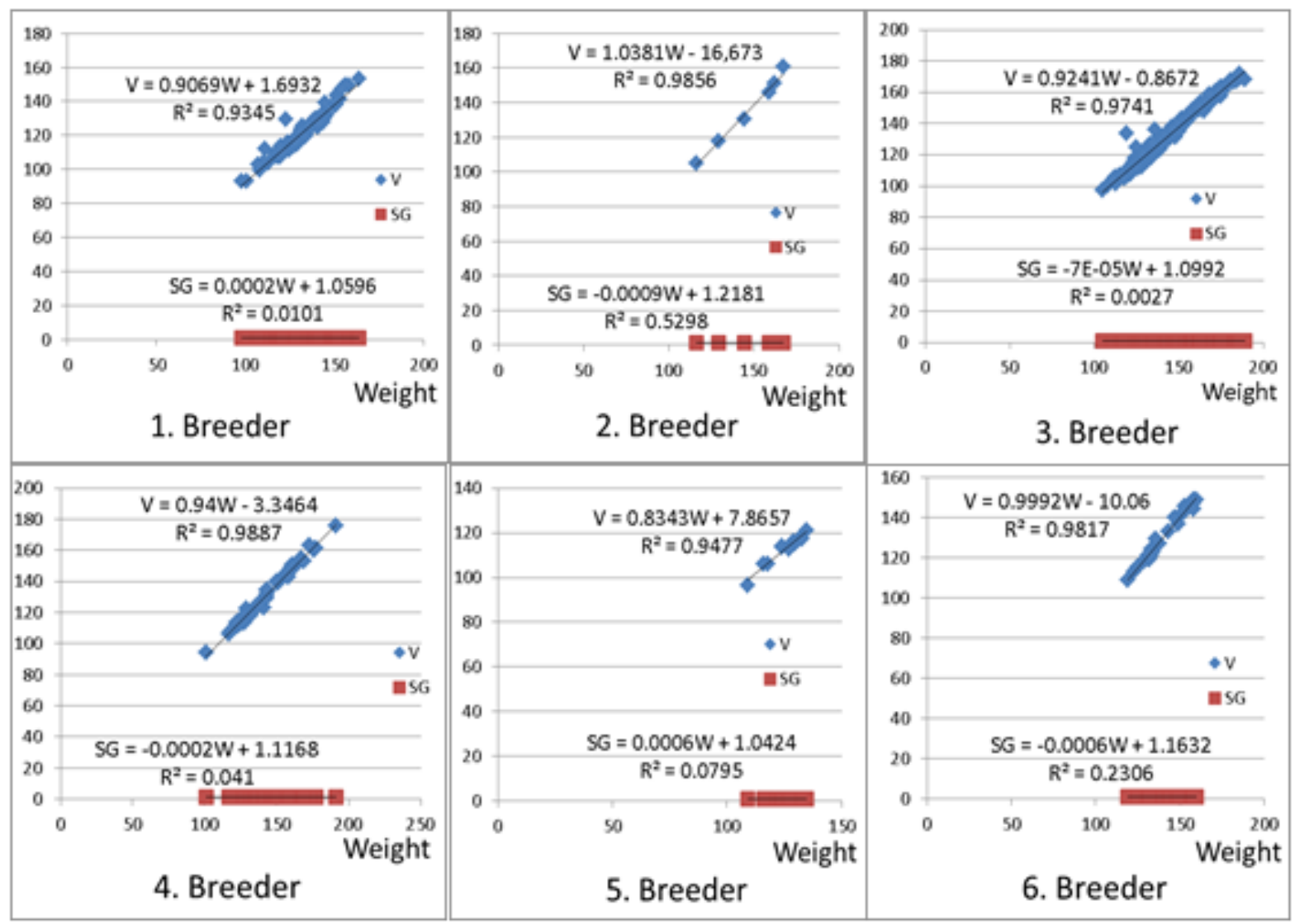

Figure 2. Regressions where Egg weight determined Egg volume and Specific gravity according to Breeders.

In the regression where egg weight determines the egg volume in Breeders, the coefficients of determination were 0.9345 , 0.9856, 0.9741, 0.9887, 0.9477 and 0.9817, from 1st Breeder to 6th Breeder, respectively. Determination coefficients have values close to 1 and a similar situation in genotypes has emerged here as well. According to Breeders, the coefficients of determination in regression, where egg weight determines the specific gravity, increased from 1st Breeder to 6th Breeder, respectively, 0.0101, 0.5298, 0.0027, $0.041,0.0795$ and 0.2306. Correlations between Egg weight, Egg volume and Specific gravity according to Breeders have been given in Table 4. A very high positive correlation was found between egg weight and volume, and it was 0.967, 0.993, 0.987, 0.994, 0.974 and 0.991, respectively, from 1st Breeder to 6th Breeder $(\mathrm{p}<0.001)$. A similar situation in genotypes was seen in Breeders. A negative correlation ( $r=-$ 0.156) was observed only in Breeder 6 between the egg weight and specific gravity variables in Breeder $(\mathrm{p}<0.01)$. This difference suggests that the 6th Breeder have kept eggs in a more humid environment during egg storage compared to other breeders. 


\section{DISCUSSION}

Average egg weights, from large to small in genotypes, have emerged 165.9, 137.2 and 131.1 $\mathrm{g}$ in Linda, Native and Chinese geese, respectively. These averages are within the range reported in the literature. However, the average found for Chinese Geese is much lower than the $173 \mathrm{~g}$ reported by Arroyo (1990). Similarly, it is lower than 144.51 and $148.43 \mathrm{~g}$ reported by Saatçi et al. (2002) and Saatçi et al. (2005) for Native geese. These differences may be originated from genetic factors such as race and age, as well as environmental factors such as care, feeding, breeding system and region differences (Hamadani et al., 2016; Arroyo, 1990; Tilki and İnal, 2004a; Razmaité, 2013). Storage time and shape may also have a contribution to this difference.

The ranking of average egg volume in genotypes is similar to that of egg weight and was calculated as $152.0,126.0$ and $120.3 \mathrm{~cm}^{3}$ in Linda, Native and Chinese geese, respectively. While the average of Linda and Native geese was within the range reported in the literature, the average of Chinese geese has been found to be low (Paganelli et al., 1974; Saatçi et al., 2002; Hamadani et al., 2016; Kumbar et al., 2016). These differences can be said for egg volume, as there is a positive correlation between volume and weight. However, storage does not affect the egg volume.

Specific gravity is similar among genotypes ( $p>0.05$ ), and it has been found as 1.092, 1.091 and $1.089 \mathrm{~g} / \mathrm{cm}^{3}$ in Linda, China and Native, respectively, from large to small. The averages have been found higher than those reported by Saatçi et al. (2002) for Native geese, similar to those reported by Hamadani et al. (2016) for Kashmir Anz geese and higher than those reported by Arroyo (1990) for Africa, China, Toulouse and Embden geese. It has also been detected to be higher than those reported for Japanese quail and chickens (Çetingül and İnal, 2009; Nemati, 2020). In addition to this being normal, the formula used in calculating the volume can be regarded as an indicator that it gives results close to reality. However, the storage time and how it's done may affect the specific gravity.

Those determination coefficients have taken values close to 1 in the regression between egg weight and volume is an indication that an egg volume that is close to the required (real-like) value can be calculated for each egg whose weight is known by using the regression formula. In the regression between egg weight and specific gravity in genotypes, the determination coefficients have occurred 0.0242, 0.0022 and 0.05 in Native, China and Linda, respectively. Even though the determination coefficients seem far from 1, the importance of the correlation between egg weight and specific gravity should be checked because the importance of correlation is directly related to the number of eggs.

Regarding with correlations between the variables, a high level of positive correlation have been detected between the egg weight and volume in Native, China and Linda, as 0.985, 0.965 and 0.989 , respectively, which seems to confirm the coefficient of determination. The fact that genotypes have the same size order of the egg weight and egg volume averages supports the existence of this correlation. Considering the correlations of specific gravity with egg weight and volume, although the negative correlation $(\mathrm{r}=-0.157)$ with egg weight in Native geese does not seem normal, the addition of a substance with a lower specific gravity than the Specific gravity of the egg may create a negative correlation (MEB, 2011). In other words, the Specific gravity of an egg, which is under the influence of a substance with a low Specific gravity, falls but its weight, increases. The first thing that comes to mind here is that the egg has been exposed to excessive moisture, and the density of water is lower than that of the egg. That the correlation of Specific gravity with volume has emerged at a higher 
level supports this view. Because the Specific gravity decreased although the egg volume remained constant, That Specific gravity has a correlation with egg volume and a positive correlation coefficient with egg weight indicates that the egg is under the influence of the high density substance. The emergence of insignificant correlations in Linda geese may indicate that they are well preserved.

Breeders were ranked as 2th, 4nd, 6th, 3th, 1th and 5th in terms of the size of average egg weights from large to small, while their weight averages were 146.2, 143.3, 140.3, 138.8, 131.8 and $125.9 \mathrm{~g}$. Although these averages are within the range reported in the literature, important differences have been found among Breeders. The reasons reported for the difference in egg weight averages of genotypes can also be said for Breeders.

The order of the average egg volume in the breeders is the same as for the egg weight and it has been calculated as 135.1, 131.4, 130.1, 127.4, 121.2 and $112.9 \mathrm{~cm}^{3}$, respectively. The ordering relationship in the genotypes was also seen in the breeder in terms of the weight and volume of the eggs averages.

In Specific gravities, the order is different from the weight and volume, and only a difference has occurred due to the height of the 5th Breeder's average Specific gravity of 1.115 $\mathrm{g} / \mathrm{cm}^{3}$. This average is close to the $1.113 \mathrm{~g} / \mathrm{cm}^{3}$ average reported only by Saatçi et al. (2002) among the reviewed literature. Having the lowest value in terms of coefficient of variance, it has been detected that the most homogeneous eggs in terms of specific gravity are in the 5 th breeder. Although the eggs have been preserved under the same conditions, regression and correlation should be considered in order to understand the height in Specific gravity.

When the regressions in which egg weight determines egg volume and specific gravity in breeders have been examined, the coefficients of determination in egg weight and egg volume have taken values close to 1, and egg weight and specific gravity have taken values far from 1 . The importance of the correlation coefficients should be checked in order to make a definite decision about the determination coefficients.

When the correlations between the variables in breeders have been examined, the correlation coefficients in egg weight and egg volume have been positive and close to 1 as in the genotypes. Therefore, the determinations about the correlations in genotypes are also valid for Breeders. When the correlations of specific gravity with egg weight and volume have been examined, it has been found that it is insignificant in 1st Breeder and 2nd Breeder ( $p>0.05$ ). It can be said that the eggs of these two Breeders have not been affected by any substance.

Correlations have been found significant and negative between Specific gravity and volume in 3rd Breeder, 4th Breeder and 5th Breeder $(\mathrm{p}<0.001, \mathrm{p}<0.01)$. The negative correlation coefficient between Specific gravity and egg weight in 3rd Breeder and 4th Breeder suggests that it has been under the influence of a substance lower than egg Specific gravity. If this substance is caused by water depending on the ambient humidity, it should be evaluated together with the ambient temperature because as the temperature increases, the volume of the substances expands and the specific gravity decreases (Erensayın, 2000; MEB, 2011). In other words, this suggests that moist eggs have been weighed in a place with high ambient temperature. For this reason, it can be said that there is an insignificant increase in egg weight but a significant decrease in specific mass. In 5th Breeder, the positive correlation coefficient of Specific gravity and egg weight may indicate the inclusion of a substance with a higher specific gravity than that of the egg or the output of a substance with a low specific gravity. The first thing that comes to mind here is the possibility that the egg has lost water. In the 6th Breeder, the correlation coefficients have been found to be 
significant and negative. Most likely the egg has moistened.

\section{CONCLUSION}

In the study, egg volume was calculated with mathematical equations and results were obtained close to reality. Accordingly, the calculated Specific gravity has also been found to be realistic. These results have been obtained easily by knowing only three variables, egg weight and Length and Breadth values. These results will be easier to obtain with photographic imaging techniques. It is thought that this method can pave the way for obtaining a lot of information about the relation between egg and specific gravity. For this, it is necessary to measure and determine the changes that occur as a result of the controlled storage of eggs obtained from controlled flocks and examine these data together with the changes in specific gravity, weight and volume.

\section{ACKNOWLEDGMENT}

Ethical approval: An ethical approval is not needed according Turkish regulations as only samples were taken for calculations.

Conflict of interest: Authors declare that they have no competing interests.

\section{KAYNAKLAR}

Adegbenjo, A. O., Liu, L. \& Ngadi, M. O. (2020). Nondestructive assessment of chicken egg fertility. Sensors; 20,5546.

Ahmad, I., Alam, M. D. J., Haque, M. D. S. \& Mamdud, M. A. A. (2017). Proximate analysis and assessment the physical characteristics of different types of duck eggs in Bangladesh. Journal of Engineering and Science Research 1(2)38-42.

Alaşahan, S., Garip, M., Çağlayan T. \& Ateş, C. (2019). Examination of some external quality traits of goose, duck and turkey eggs in public farms. Harran University Journal of The Faculty of Veterinary Medicin, 8(1),21-25.

Arroyo, C. L. (1990). Specific gravity, weight and the percentage of shell, white and yolk in goose eggs. Agronomía Costarricense, 14(1), 99-102.
Arslan, C. \& Saatçi, M. (2003). Egg yield and hatchability characteristics of native geese in the Kars Region. Turkish Journal of Veterinary and Animal Sciences, 27(6),136-365.

Carey, C. (1994). Structural and physiological differences between montane and lowland avian eggs and embryos. Journal of Biosciences, 19(4), 429-440.

Çetingül, İ. S. \& İnal, F. (2009). The effects of hazelnut and sunflower oil used in the diets of layer hens and broilers on performance and fatty acid composition of animal products. Revue de Medecine Veterinaire, 160(4), 197-203.

Çopur-Akpınar, G., Alaşahan, S. \& CanoğullarıDoğan, S. (2017). Determination of the egg quality characteristics with mathematical formulas in pekin ducks grown in public farms. Turkish Journal of Agriculture - Food Science and Technology, 5(12), 1470-1475.

ÇŞB (2021, April 27). Aksaray İli Temiz Hava Eylem Plant-THEP (2014-2019). https://webdosya.csb .gov.tr/db/aksaray/webmenu/webmenu13783.pdf

Erensayın, C. (Eds). (2000). Bilimsel-teknik-pratik tavukçuluk 3. Nobel Yayın Dağıtım.

Eskin, B., Tuncer, M., Uslu-Divanoğlu, S. \& Avan, A. (2017). Dynamics of Aksaray province. The Journal of Academic Social Science, 5(61), 237-248.

Golze, M. (1991). Four years of use and the right time of hatching result in more hatching eggs and goslings for laying geese. Tierzucht, 45, 524-526.

Hamadani, H., Khan, A.A., Sofi, A, H., Salahuddin, M. \& Bihaqi, S. F. A. (2016). Quality traits and grades of geese eggs produced under local conditions of Kashmir. Indian Journal of Poultry Science, 51(2), 192-195.

Hamilton, R. M. G. (1982). Methods and factors that affect the measurement of egg shell quality. Poultry Science, 61, 2022-2039.

Hoyt, D. F. (1979). Practical methods of estimating volume and fresh weight of bird eggs. American Ornithological Society, 96, 73-77.

IBM (2013). SPSS Statistics. version 22.

Karabulut, O. (in press). Estimation of External Quality Characteristics of Goose Eggs of Known Breadth and Length. Veterinární Medicína.

Karabulut, O., Ün, H., Çamkerten, İ., Garip, M. \& Bulut G. (2017). Aksaray yöresi kazlarda kuluçka randımanı üzerine araştırmalar. Journal of Bahri Dagdas Animal Research, 6(1), 13-22.

Kumbar, V., Nedomova, S., Trnka, J., Buchar, J. \& Pytel, R. (2016). Effect of storage duration on the rheological properties of goose liquid egg products and eggshell membranes. Poultry Science, 95, 1693-1701.

Lawrence, K. C., Smith, D. P., Windham, W. R., Heitschmidt, G. W. \& Park, B. (2006). Egg embryo development detection with hyperspectral imaging. International Journal of Poultry Science, 5(10), 964969.

MEB (2019, April 27). Glda teknolojisi yoğunluk ve kıvam ölçümü. Türkiye Cumhuriyeti Millî Eğitim Bakanlığ1, Ankara. http://megep.meb.gov.tr/mte_program_modul/modull er_pdf/Yo\%C4\%9Funluk $\% 20 \mathrm{Ve} \% 20 \mathrm{~K} \% \mathrm{C} 4 \%$ B 1 vam $\% 20 \% \mathrm{C} 3 \% 961 \% \mathrm{C} 3 \% \mathrm{~A} 7 \% \mathrm{C} 3 \% \mathrm{BCm} \% \mathrm{C} 3 \% \mathrm{BC}$.pdf 
Narushin, V. G. (2005). Production, modeling, and education-egg geometry calculation usingthe measurements of length and breadth. Poultry Science, 84(3):482-484.

Nedomová, ড̌. \& Buchar, J. (2014). Goose eggshell geometry. Research in Agricultural Engineering, 60,100-106.

Nemati, Z., Ahmadian, H., Besharati, M., Lesson, S., Alirezalu, K., Domínguez, R. \& Lorenzo, J. M. (2020). Assessment of dietary selenium and Vitamin $E$ on laying performance and quality parameters of fresh and stored eggs in Japanese Quails. Foods, 9(9), 1324.

Önk, K. \& Kirmızibayrak, T. (2019). The egg production, hatchability, growing, slaughterand carcass characteristics of geese (Anser Anser) reared under breeders conditions in Kars province; I. Egg production and hatchability characteristics. Turkish Journal of Agriculture-Food Scienceand Technology, 7(3), 543-549.

Özbey, M. (1998). Kars Kazcllı Üretme İstasyonunda yetiştirilen Fransız beyazı (INRA) ırkı kazların yumurta verimi ve kuluçka özellikleri (Publication No. 49927) [Yüksek lisans tezi, Kafkas University]. YÖK Tez Merkezi.

Paganelli, C. V., Olszowka, A. \& Ar, A. (1974). The avian egg: surface area, volume, and density. The Condor, 76(3), 319-325.

Preston, F. W. (2010). The volume of an egg. American Ornithological Society 1974; 91:132-138.

Rabsztyn, A., Andres, K. \& Dudek M. (2010). Variability, heritability and correlations of egg shape in the Zatorska goose. Journal of Central European Agriculture 11(4), 433-436.

Rahn, H., Carey, C., Balmas, K., Bhatia, B. \& Paganelli, C. V. (1977). Reduction of pore area of the avian eggshell as an adaptation to altitude. Proceedings of the National Academy of Sciences, 74, 3095-3098.

Ramos, M., Gonzales, O., Avila A., Perez, Z., Guash, S., Diz, M., Puente, D. \& Toledo, E. (1989). Effect of wiping or washing on the hatching results of goose eggs. Rev. Avicult, 33, 163-172.

Razmaitė, V., Šveistienė, R. \& Švirmickas, G. J. (2013). Effect of laying stage on egg characteristics and yolk fatty acid profile from different-aged geese. Journal of Applied Animal Research, 42(2), 127-132.

Saatci, M., Kırmızıbayrak, T., Aksoy, A. R. \& Tilki, M. (2005). Egg weight, shape index and hatching weight and interrelationships among these Traits in Native Turkish Geese with different coloured feathers. Turkish Journal of Veterinary and Animal Sciences, 29, 353-357.

Saatçi, M., Yardımcı, M., Kaya, İ. \& Poyraz, Ö. Kars İli Kazlarında Bazı Yumurta Özellikleri. Lalahan Hayvancılık Araştırma Enstitüsü Dergisi, 42(2), 37-45.

Sunardi, S., Yudhana, A. \& Saifullah, S. (2017). Identity analysis of egg based on digital and thermal imaging: image processing and counting object concept. International Journal of Electrical and Computer Engineering, 7(1), 200-208.

Tilki, M. \& İnal, Ş. (2004a). Yield traits of geese of different origins reared in Turkey I. Hatching traits. Turkish Journal of Veterinary and Animal Sciences, 28(1), 149-155.
Tilki, M. \& İnal, Ş. (2004b). Quality traits of goose eggs. 1. Effects of goose age and storage time of eggs. European Poultry Science, 68, 182-186.

Toth, S. (1991). Development of goose for fat liver production part III. Efforts in establishing a synthetic population from landaise and hungarian breeds. Bulletin of the University of Agricultural Sciences, Godollo, 77-88.

Yayvan, M., Çelik, S. \& Ersoy, S. (2008). Aksaray iklimi ve küresel 1sınma. Su Enerji Sağllk Sempozyumu; Ekim 20-23; Aksaray. Türkiye. 